\title{
Obligation of Indonesian Advocates to Report on Client's Suspicious Financial Transactions in Legal Enforcement Perspective
}

\author{
Taufiqurrahman $^{1}$ and Elok Dwi Indriastuty ${ }^{2}$ \\ \{taufiqurrahman@uwp.ac.id ${ }^{1}$ \} \\ ${ }^{1,2}$ University of Wijaya Putra, Surabaya, Indonesia
}

\begin{abstract}
Based on the provisions of Article 3 letter a Government Regulation Number 43 of 2015 concerning Reporting Parties in the Prevention and Eradication of Money Laundering (GR-RPPEML), advocates with other professions are obliged to report to the Center of Financial Transaction Reports and Analysis Center (CFTRA) for suspicious financial transactions. At the implementative level, this provision raises serious legal problems for Advocates in doing their profession. Article 19 paragraph (1) of Act Number 18 of 2003 on Advocates (AoA) expressly determines that an advocate must keep everything known or obtained from his client because of his professional relationship, unless otherwise stipulated by law. The purpose of this study is to find out the legal position of the provisions that oblige the Indonesian advocates to report suspicious financial transactions as referred to in Article 3 letter a of such GR-RPEML. The type of research used is normative legal research with a legal approach and a case approach. The results showed that the provisions requiring advocate profession to report suspicious transactions as referred to in Article 3 letter a of such GR-RPEML do not have a strong legal basis, so it is open to the advocate profession not to carry out these obligations as a reflection of obedience to the AoA itself.
\end{abstract}

Keywords: Obligation, Report, Suspicious, Financial Transaction, Legal Enforcement

\section{Introduction}

This is a fact that can not be denied that at the time of implementation of the ASEAN Economic Community (AEC) which should require all member of ASEAN countries to have concentration, creativity, inovation, synergy and speed of action to win the regional competition of ASEAN, precisely Indonesia is preoccupied with domestic problems which ultimately has the potential to deprive itself of the acquisition of the victory of the competition [1]. One of the domestic issues takes a long time, attention and cost which it is not a bit is the occurrence of financial crimes.

As in other countries, financial crimes in Indonesia have diversity of kinds, which are a corruption, money laundering, drugs, tax, fraud and so forth [2]-[4]. Financial crimes in Indonesia from time to time does not indicate a decline, both in quality and quantity, but on the contrary showed a significant increase, particularly with respect to the crime of corruption [5]. In this regard, Indonesia Corruption Watch (ICW) in a press release dated February 24, 2016 states that the number of corruption cases in the year 2010 to 2014 as many as 2,492 cases with the losses amounting to Rp. 30 trillion, by 2015 as many as 550 cases with the losses to the state 
amounting to Rp. 31.077 trillion. ${ }^{1}$ The trend of rising levels of corruption crimes was also corroborated by the Deputy Director of the Corruption Criminal Investigation Police stating that corruption cases handled by the Police until the investigation process in the year 2010 as many as 176 cases in 2011 as many as 432 cases in 2012 as many as 591 cases in 2013 as many as 424 cases and in 2014 as many as 569 cases. $^{2}$

It's not a secret anymore that the financial crimes including the crime of corruption is bound to cause a great losses for a country (in this case Indonesia) [6], [7]. In cumulatively, the state's losses arising from financial crimes this in turn will affect the rate of national economic growth of Indonesia, and this in turn will potentially undermining to the efforts to achieve national goals expected, namely the actualization of Indonesian society that is fair, and prosperous as mandated by the Constitution of 1945 .

Recognizing that the magnitude of the consequences of the financial crimes for the sustainability of the nation and state of Indonesia in the future, the government issued Government Regulation No. 43 Year 2015 concerning the Reporting Parties in the Prevention and Eradication of the Money Laundering (GR-RPPEML). Through this regulation, as set out in Article 3, the government has included Advocates profesion as the parties must report to the Center for Financial Transaction Reporting and Analysis (CFTRA) based on information about suspicious transactions obtained from his client. The Advocate must report for the actualization of the terms "Customer Due Diligent " as stipulated in Article 4 GR-RPPEML. According to Article 4 of this, other than Advocate profession subject to the obligation to report financial transactions client was a Notary, Land Titles Registraar, Accountants, Public Accountants and Financial Planners. This arrangement did not like exist previously in the Act Number 8 Year of 2010 on the Prevention and Eradication of Money Laundering (A-PEML).

Based on the above-mentioned phenomena, it is interesting to be observed is the presence of Advocate profession itself in the dynamics of law enforcement process of financial crime in Indonesia. In this perspective, the Advocate is positioned very dilemma. On the one hand, an Advocate as a member of the public in general are required legally and morally to engage in the prevention and eradication of the crime through the provision of financial information obtained from the client regarding suspicious financial transactions. But on the other hand, an Advocate as demanded by the laws and professional codes of conduct are not only required to defend the legal interests of his client suspected and charged with a criminal offense finances optimally, but also required to keep "confidential information" from his client to a third party at any time.

This paper is oriented to analyze the validity of setting a legal obligation for Advocate to provide a report to a third party in cases of alleged criminal acts of the financial information obtained from clients.

\footnotetext{
${ }^{1}$ Crimes of corruption that occurred during the year 2015, carried by various modes. First, the mode of misuse of funds carried out as many as 134 cases or $24 \%$ with total losses amounting to Rp. 803.3 billion. Second, the mode of evasion done as many as 107 cases with a value of state losses of Rp. 412.4 billion. Third, inflation mode as many as 104 cases with a value of state losses of Rp. 455 billion. Fifth, the mode of 102 cases of abuse of authority by the state loss of Rp. 991.8 billion.

From the numerous cases of corruption, ICW noted that the Public Prosecution to handle as many as 369 cases with total losses amounting, police handle 151 cases with a total value of state losses of Rp. 1.1 trillion and the Corruption Eradication Commission (CEC) 30 cases with a value of state losses of Rp. 722.6 billion.

2 "ICW: Public Service Sector Most Range of Corruption", February 25, 2016, <ti.or.id> accessed on 15 May 2016. See also "Developments of Corruption Trends in First Half 2015" in the Weekly Bulletin AntiCorruption, dated 18 September 2015, <okezone.com> accessed on May 15, 2016, also <antaranews.or.id>
} 


\section{The existence of advocate under the act on advocate}

Since the enactment of Act No. 18 Year of 2003 on Advocates (AoA), Advocates entered a new phase. Advocates not only as a party who defends the legal interests of their client partially, but more than that laterally they has a duty and a great responsibility to uphold the truth, law and justice. In an effort to defend the legal interests of their client, an advocate must refrain from legal actions that actually violates the law itself . Instead, he is demanded to uphold the values of truth, law and justice. In this regard, namely their duties and responsibilities are great in law enforcement efforts in Indonesia, only natural that presence status equated with other legal profession (in this case Judge, Prosecutor and Police ), namely as law enforcement authorities. Therefore, law enforcement pillar before the entry into force AoA known as Tri Wangsa (Judges, Prosecutors and Police), has now turned into Catur Wangsa (Judges, Prosecutors, Police and Advocates) .

As law enforcement officers, Advocates as well as Judges, Prosecutors and Police are required to make efforts in the prevention and eradication of every criminal action in Indonesia, including financial crimes. Moreover, it was realized that due to the loss of the financial crime is not only felt by per person individually, but it is also felt by the community, nation and state of Indonesia in a longer time perspective. Therefore, based on the AoA, actually an Advocate in criminal cases assume two main missions, namely the individual mission and the institutional mission.

Advocate's individual mission is to provide legal assistance optimally based on the legislation in force and the code of professional ethics for the benefit of his clients subjectively, either leniency or exemption of punishment. While the institutional mission of Advocate is attempting to find a legal settlement of cases handled by the legislation in force and the code of professional ethics for the larger interest, namely the establishment of the truth, law and justice.

Both missions that should be considered and implemented by an Advocate. In the exercise of their profession, they did not merely pursue his client's interests and benefits subjectively by subjecting a greater importance, namely the establishment of the truth, law and justice. And vice versa, an Advocate is not allowed to ignore and even sacrifice the interests of their client subjectively in the pursuit of greater interest. Both of these interests, the mission of individual and institutional mission, must be implemented simultaneously and balanced. Article 3 letter b of Code of Indonesian Advocates Ethics (CoIAE) imposes that Advocates in carrying out their duties are not solely to obtain material benefits, but prefers the rule of law, truth and justice.

Advocates who in the execution of their profession having honorable mission, both for the benefit of subjective and objective interests of its clients for the sake of truth, law and justice, in principle they actually carry respectable profession (officium nobile). Even Advocates under AoA is an honorable profession, but not necessarily substantively he can be said to have been carrying out an honorable profession. It is very likely to happen when in fact Advocate in the execution of his profession only defend the interests of his client subjectively and ignore objective interests for the sake of truth, law and justice.

\subsection{The principle of confidentiality in relation advocate - clients}

Every person who has the legal issue is entitled to receive legal assistance by one or more of the Advocate in efforts to resolve the legal issues he faces. Right to legal aid is strictly 
regulated in Article 54, Article 55 and Article 56 of the Act No.18 Year 1983 on the Criminal Procedure Code (AoCPC). In asking for the help of lawyer's legal services, a candidate of clients will surely effort to find an advocate who can actually realize her hope. In criminal cases, particularly related to financial crimes, of course, prospective clients suspected of having committed financial crimes, it is rational when he was pinned their hopes to a lawyer to seek his release from punishment or at least seek leniency.

A person requesting assistance of legal services to Advocate for tangled legal issues is not necessarily as offenders alleged by law enforcement officers, both police, prosecutors or the Commission of Corruption Eradication. Even factually prospective clients are perpetrators, a lawyer is ethically not allowed to state that he/she is a criminal. Paradigm that must be developed to underpin the relationship between the advocate with a prospective client or client is the principle of "presumption of innocence". By putting this principle before the start the relationship between the lawyer with the client, the lawyer can move freely to get as much information as possible for the benefit of setting the strategy in handling cases entrusted to him in the absence of significant psychological barrier.

In accordance with the AoA, the Advocate is obliged to provide legal aid to any person requesting his/her legal services. Advocate who refuses to handle the requested legal aid by someone in need of legal services can be considered as a violation of the Advocate's oath / pledge as stipulated in Article 4 paragraph (2) AoA. Even Advocate may not refuse requests for legal assistance from someone who needs it, does not mean the door for a rejection of the Advocate completely closed. CIAE provide space for the Advocate to refuse requests from prospective clients legal services. As stipulated in Article 3 letter a, Article $4 \mathrm{~g}$, and Article 4 letter $\mathrm{j}$ of CIAE, Advocate can reject the request of legal assistance based only on three (3) conditions, namely: it is not complying with the expertise and contrary to his conscience, the case was no legal basis and there was conflic interested.

For the purposes of defense, the relationship between advocates and clients should be built a "bridge of trust". Belief will present itself when each party, and advocate-client, there is an attitude of "open", "honest" and "responsible". If you've established trust between Advocate with the Client, the Client will deliver all any information honestly and openly to advocate because he believes that the Advocate will carry out their profession responsibly with the ability to keep confidential all information obtained from clients, other than just for the sake her defense.

In regard to the responsibilities of the Advocate to conceal any information obtained from Clients to third parties, Article 4 letter CIAE expressly specify an obligation to advocate to keep the confidentiality of information about his client until whenever. This means that the completion of the legal relationship between an Advocate with His client did not limit liability for Advocate to keep information about the Clients.

\subsection{Reporting on financial transactions client by advocate}

As mentioned a little earlier, Advocate obligation to report his/her clients' suspicious transactions was not based on Act No. 8 Year 2010 (A-PEML), but it is based on GR-RPPEML. Article 3 of this Regulation (GR-RPPEML) explicitly states that the Advocate, Notary, PPAT, Accountants-Certified Public Accountants, Financial Planner is obliged to report to the CFTRA. This reporting obligation as a realization of the principle of "Know Your Customer " (customer due diligence) as stipulated in Article 4 GR-RPPEML. The obligation to report financial transactions of clients by advoctes and other professions, namely Notary PPAT, Accountant, 
Certified Public Accountants and Financial Planners previously not regulated in Act 2010 (APPEML).

The inclusion of Advocates as a reporting party in the GR-RPPEML indicate a strong stigma in society that advocate is a profession that is vulnerable to financial crimes. All the actors in the financial crime rescue him from the law and or rescue richness of the proceeds of crime in order not to be separated from his mastery, then they will ask for the help of legal services to the Advocate. Even though possessions are not the result of evil, but in an effort to obtain greater profits in a way that is contrary to law and morals, not infrequently they also sought the help of legal services to the Advocate.

Case "Panama Papers" that appear in the month of April 2016 and then reinforce the negative stigma of society to the Advocate. The case is shocking the international community after the International Consortium of Investigative Journalists (ICIJ) published a report on the results of the analysis measuring 2.6 documents accompanied by 149 terabytes of file documents involving around 400 journalists from 107 media organizations on April 3, 2016. The secret files made by Panama origin service providers, law firm Mossack Fonseca. This document contains detailed information on more than 214,000 companies abroad, including the identity of the shareholders and directors. The document includes the name of the leader of the five countries, Argentina, Iceland, Saudi Arabia, Ukraine, and the United Arab Emirates, as well as government officials, close relatives, and close friends a number of heads of governments of about 40 countries. The law firm founded by Jürgen Mossack and Ramón Fonseca in 1977 provides company formation services in other countries, management of foreign companies, and asset management. The company has more than 500 employees in 40 countries. The agency operates on behalf of more than 300,000 companies, mostly registered in the United Kingdom or the tax haven Britain. The firm works closely with financial institutions world such as Deutsche Bank, HSBC, Société Générale, Credit Suisse, UBS and Commerzbank. The agency sometimes help bank customers to build complex structures that tax collectors and investigators hard to track the flow of money from one place to another. More than 200 people of Indonesia, both employers and state officials, is named in the document is confidential. Apart from the substantive truth of the names of Indonesian people who are in the document, the legal act of forming companies outside Indonesia, the management of overseas companies and asset management in tax havens involve Advocates, in this law firm Mossack Fonseca.

Financial crime in all its forms is clearly detrimental to the country in an effort to improve the welfare and prosperity of society in general. In the current development ni, financial crimes in Indonesia has been a terrifying ghosts that always overshadow any development efforts done and most likely any time plunged Indonesia into the deepest abyss. Therefore, logically and rationally when all the existing potential of the nation, including Advocates, together to prevent or avoid the occurrence of financial crimes. All the potential of the nation, not to mention Advocate profession, must have commitment, willpower and a high awareness to prevent the occurrence of financial crimes.

How actualization of commitment, willpower and a high awareness Advocates in law enforcement efforts with financial crimes related to obligation as a reporting party on clients“ financial transactions to CFTRA ? Do actualization of commitment, willpower and a high awareness for an Advocate can be interpreted that obligation as mandated by GR-RPPEML should be implemented without any exceptions? The critical question is not easily answered, it takes us to deeper study.

As described previously, the Advocate in the execution of his profession, even standing on the foundation of self-reliance, he remains constrained by the code of profession ethics and national legislation. CIAE is the supreme law that must be obeyed by all the Advocates. CIAE 
require to all Advocates for upholds truth, law and justice as an objective goal of the defense is done without violating the rights and dignity is a subjective interest of their client. In this context, to be able to answer critical questions above, the parameter is whether the normative provisions requiring Advocates as a reporting party on their client's suspicious financial transactions to CFTRA as mandated in Article 4 GR-RPPEML lawful or not. When the existence of this norm is lawful, there is no reason for Advocates for not doing command of GR-RPPEML. Conversely, if the existence of this norm is not lawful, then there is no reason for Advocates for not doing command of GR-RPPEML. This is all done by the Advocate in an effort to uphold the law, in addition to truth and justice.

Testing against the norm if there is a conflict with other norms either vertically or horizontally can be done by applying some of the principles of law. In the vertical test, one of the legal principles that can be applied to test for the existence of norms that require the Advocate as the Reporting Parties under Article 3 GR-RPPEML is "lex superior derogat legi inferior". This legal principle implies that a higher law ignores the lesser law. In connection with the adoption of this legal principle, whether Article 3 GR-RPPEML contrary to law.

Article 17 paragraph (1) of the Act 2010 (A-PEML) determines that the parties qualified as the Reporting Party is the provider of financial services consisting on 16 companies or institutions and providers of other goods or services which consists of five companies or institutions. In this provision, the Advocate is not included as a Reporting Party. Although the act (A-PEML) does not regulate the Advocate as the Reporting Party, does not mean that Article 3 GR-RPPEML is contrary to law. This is because Article 17 paragraph (2) of the A-PEML expressly provides that "Provisions on the Reporting Parties other than those referred to in paragraph (1) shall be regulated by Government Regulation". This means that the settings in GR-RPPEML which including Advocate as Party Reporting get reinforcement of Article 17 paragraph (2) of the A-PEML. In other words that there is no contradiction between the norms of the Act related to Advocate obligations as a Party Reporting. In this context also, substantively, in fact the A-PEML accommodate parties beyond those referred to in Article 17 paragraph (1) as the Reporting Party, including the Advocate.

Furthermore, in the horizontal testing, one of the legal principles that can be applied to test is the "lex specialis" principle of law. This legal principle implies that the more specialized law ignores the law more generally. In connection with the adoption of this legal principle, whether Article 3 GR-RPPEML is contrary to AoA.

Article 19 of the AoA states that The Advocate must keep everything that is known or obtained from Clients for relations profession, unless otherwise stipulated by the Law. Furthermore, The Advocate is entitled to confidential relationship with clients, including protection for files and documents to foreclosure or inspection and protection against eavesdropping on electronic communications Advocate. Based on Article 19 of the AoA, then maintain the confidentiality of the information obtained from the client is a legal obligation that must be carried out by the Advocate. Even for this purpose, the Advocate has the right to confidentiality relationship with Clients, including the protection of all files and documents from seizure and examination. This means that the provision of information concerning the confidentiality from their clients to third parties is a violation of the AoA. AoA sealed the principle of client confidence through the secure client confidentiality.

Advocates's legal obligation to keep a secret any information it receives from their client was also accomodated by CIAE in which it is the supreme law for the Advocate. It is strictly regulated in Article 4 letter h CIAE which states "Advocate shall hold office secrets about things that are notified by the client in trust and must keep it confidential after the end of the relationship between lawyers and clients that". Under the provisions of CIAE, legal obligation 
to keep confidential, it is not just limited to the promulgation of the relationship between the Client Advocate, but until after the end of the relationship.

Judging from the degree of applicability of the A-PEML with AoA for Advocates, APEML general nature and thus binding to all the people of Indonesia as a whole, while the AoA is specific and therefore only binding for the whole of the Indonesian Advocates. Therefore, basing degree of enforceability and associated with the application of "lex specialist derogate legi generali", then that applies to an Advocate is maintaining client confidentiality to any time, including information about any suspicious transactions.

Even under the provisions of Article 19 AoA jo. Article 4 letter h CIAE, Advocate is given the obligation to maintain the confidentiality of his clients until whenever, but this does not mean for an Advocate no obligation to prevent financial crimes. Obligation to enforce a financial crimes attached to all law enforcement officers, including Advocate. In the context of the financial transactions of suspicious after analysis of information obtained from the client, the Advocate may provide legal advice to clients to report it to the CFTRA. The legal advice given, of course, is not imperative, but optional. Fully restored to the legal awareness of clients, whether to report or not, it depends on the will of the client itself.

Efforts solutif offered as above is more partial, indivual and not touching the substance of its aspects. For the sake of it, the substance AoA. Based on Article 19 AoA must be harmonized in advance with the contemporary requirements as stipulated in Article 17 of APEML jo. Article 3 APEML. With the harmonization of substance in Article 19 of the A-PEML to the current state of emergency, then the psychological barrier for the Advocate as an obligation on the Reporting Party can be minimized.

\section{Conclusion}

Based on analyses as mentioned above, it can be concluded that Advocate can not be qualified as a reporting party on client's suspicious transactions to CFTRA as stated in Article 3 GR-RPPEML. This is because contrary to Article 19 AoA in conjunction with Article 4 letter $\mathrm{h}$ CIAE which imposes a duty to advocate to keep confidential information obtained from Clients until the end of the relationship between the Advocate-Client.

Given the impact of the financial crimes immense, ie inhibition of efforts to boost national economic growth, which in turn affect the efforts to achieve national goals, it is advisable to the legislative to synchronize the substance of Article 19 AoA which closes all of the information to the Third Party (CFTRA) with Article 17 of A-PEML jo. Article 3 A-PEML.

\section{Acknowledgement}

Thank you very much for Rector of University of Wijaya Putra supporting financially this reasearch under the Internal Research Grant 2019.

\section{References}

[1] K. Kourtit and P. Nijkamp, 'Creative actors and historical-cultural assets in urban regions', Reg. Stud., 2019.

[2] M. Levi, 'Financial Crimes', in The Oxford Handbook of Crime and Public Policy, 2012.

[3] S. F. A. Jabbar, 'Financial crimes: Prohibition in Islam and prevention by the Shari 'a Supervisory Board of Islamic financial institutions', J. Financ. Crime, 2010. 
[4] P. Michel, 'Financial crimes: the constant challenge of seeking effective prevention solutions', J. Financ. Crime, 2008.

[5] F. Fauzi, K. Szulczyk, and A. Basyith, 'Moving in the right direction to fight financial crime: prevention and detection', Journal of Financial Crime. 2018.

[6] H. Seldadyo and J. de Haan, 'The determinants of corruption: A literature survey and new evidence', EPCS Conf. Turku, Finland, April 2006, 2006.

[7] S. Kimeu, 'Corruption as a challenge to global ethics: The role of Transparency International', J. Glob. Ethics, 2014. 